\title{
A One-Drug Strategy is Needed to Attenuate the Multi-Proteinopathy that Leads to Age-Related Diseases
}

\section{Ben A. Bahr}

Biotechnology Research Center, University of North Carolina - Pembroke, Pembroke, NC, USA

*Corresponding author: Ben A. Bahr, Biotechnology Research and Training Center, One University Drive, Pembroke, North Carolina 28372-1510, USA, Tel: 9107754383; Fax: 9107754383; E-mail: bahr@uncp.edu

Rec date: Mar 2, 2015; Acc date: Apr 27, 2015; Pub date: Apr 30, 2015

Copyright: (c) 2015 Bahr BA. This is an open-access article distributed under the terms of the Creative Commons Attribution License, which permits unrestricted use, distribution, and reproduction in any medium, provided the original author and source are credited.

\section{Introduction}

Alzheimer's disease (AD), frontotemporal dementia (FTD), and amyotrophic lateral sclerosis (ALS) are age-related protein accumulation disorders. They exhibit multi-proteinopathy involving tau and TAR DNA-binding protein 43 (TDP43), and the latter two disorders can also accumulate fused in sarcoma protein (FUS). AD is the most common multi-proteinopathy with an additional and perhaps key pathogenic contributor being the $\mathrm{A} \beta 42$ peptide. $\mathrm{AD}$ can also exhibit the accumulation of $\alpha$-synuclein, a key protein that accumulates in Parkinson's disease (PD) and related Lewy body diseases. The specific disorders that constitute FTD have a high proportion of familial or inherited cases, whereas less than $5 \%$ of AD cases and $5-10 \%$ of ALS cases are the familial inherited form, and the cause of the remaining $90-95 \%$ of sporadic AD and ALS cases is not fully understood. Many of the molecular and cellular features related to combinations of protein accumulation events are observed in both sporadic and familial forms of these disorders, often occurring for many years before symptoms arise. The multiple protein accumulation/aggregation events may elicit separate degenerative pathways in distinct age-dependent manners, culminating with the enhanced risk of developing one of several protein accumulation disorders (AD, FTD, ALS, PD, Huntington's disease, multiple system atrophy, multisystem proteinopathy).

Potential drugs that only target one type of pathogenic accumulation event $(\mathrm{A} \beta 42)$ have failed in recent human trials for $\mathrm{AD}$. Thus it is becoming apparent that waiting for individual therapeutics against $\mathrm{A} \beta 42$, tau, TDP43, and $\alpha$-synuclein, to allow for a combination treatment of the multi-proteinopathy in $\mathrm{AD}$, is not a hopeful outlook. ALS and FTD may also need a drug that prevents FUS accumulation and its recruitment of other proteins into aggregates. A single drug development strategy is needed that can counteract the slow clearance common among the listed proteins. Strategies to enhance clearance of multiple types of proteins are guiding efforts to find new drug targets. The autophagy-lysosomal system is a logical target since lysosomes are a primary site for protein clearance in cells.

The lysosomal pathway is critical for cellular homeostasis, providing efficient digestion and turnover of proteins, and contributing to cell health and perhaps longevity as well [1]. The lysosomal enzyme cathepsin $B$ was discovered to degrade $A \beta 42$ through carboxy-terminal truncation [2], and positive cathepsin $B$ modulation effectively reduced pathogenic $A \beta$ assemblies and ameliorated synaptic and behavioral deficits in $\mathrm{AD}$ mouse models [2-5]. Currently, enhancing the autophagy-lysosomal pathway of protein clearance is becoming widely accepted as a plausible treatment avenue for many indications, including CNS, metabolic, inflammatory, infectious, and muscle disorders [5-10]. Regarding the treatment of multi-proteinopathy, small-molecule cathepsin B modulators not only reduce intracellular $A \beta$, and consequently extracellular $A \beta$ levels, they also reduce pathogenic forms of tau, and for both $A \beta$ and tau, their enhanced clearance was associated with recovery of synaptic proteins [11,12]. In addition, an 18-residue peptide that promotesthe lysosomal degradation pathway of autophagy was found to enhance clearance of polyglutamine aggregates related to Huntington's disease [13]. These studies indicate the progress in finding a single target that enhances autophagylysosomal efficiency, thereby promoting clearance of those proteins implicated in multi-proteinopathies. Such a target is critical for developing a treatment to slow the onset and/or progression of agerelated protein accumulation disorders.

\section{References}

1. Folick A, Oakley HD, Yu Y, Armstrong EH, Kumari M, et al. (2015) Aging. Lysosomal signaling molecules regulate longevity in Caenorhabditis elegans. Science 347: 83-86.

2. Mueller-Steiner S, Zhou Y, Arai H, Roberson ED, Sun B, et al. (2006) Antiamyloidogenic and neuroprotective functions of cathepsin B: implications for Alzheimer's disease. Neuron 51: 703-714.

3. Butler D, Hwang J, Estick C, Nishiyama A, Kumar SS, et al. (2011) Protective effects of positive lysosomal modulation in Alzheimer's disease transgenic mouse models. PLoS One 6: e20501.

4. Wang C, Sun B, Zhou Y, Grubb A, Gan L (2012) Cathepsin B degrades amyloid-I in mice expressing wild-type human amyloid precursor protein. J Biol Chem 287: 39834-39841.

5. Bahr BA, Wisniewski ML, Butler D (2012) Positive lysosomal modulation as a unique strategy to treat age-related protein accumulation diseases. Rejuvenation Res 15: 189-197.

6. Liang Q, Ouyang X, Schneider L, Zhang J (2011) Reduction of mutant huntingtin accumulation and toxicity by lysosomal cathepsins $\mathrm{D}$ and $\mathrm{B}$ in neurons. Mol Neurodegener 6: 37.

7. Usenovic M, Tresse E, Mazzulli JR, Taylor JP, Krainc D (2012) Deficiency of ATP13A2 leads to lysosomal dysfunction, Ît-synuclein accumulation, and neurotoxicity. J Neurosci 32: 4240-4246.

8. Rubinsztein DC, Codogno P, Levine B (2012) Autophagy modulation as a potential therapeutic target for diverse diseases. Nat Rev Drug Discov 11: 709-730.

9. Lucin KM, Wyss-Coray $\mathrm{T}$ (2013) Targeting autophagy for disease therapy. Nat Biotechnol 31: 322-323.

10. Bahr BA (2014) A single pathway targets several health challenges of the elderly. Rejuvenation Res 17: 382-384.

11. Bendiske J, Bahr BA (2003) Lysosomal activation is a compensatory response against protein accumulation and associated synaptopathogenesis--an approach for slowing Alzheimer disease? J Neuropathol Exp Neurol 62: 451-463.

12. Viswanathan K, Hoover DJ, Hwang J, Wisniewski ML, Ikonne US, et al. (2012) Nonpeptidic lysosomal modulators derived from z-phe-aladiazomethylketone for treating protein accumulation diseases. ACS Med Chem Lett 3: 920-924. 
Citation: Bahr BA (2015) A One-Drug Strategy is Needed to Attenuate the Multi-Proteinopathy that Leads to Age-Related Diseases. J Gerontol Geriatr Res 4: 212. doi:10.4172/2167-7182.1000212

Page 2 of 2

13. Shoji-Kawata S, Sumpter R, Leveno M, Campbell GR, Zou Z, et al. (2013)

Identification of a candidate therapeutic autophagy-inducing peptide.

Nature 494:201-206. 